\title{
Phospholipids of Escherichia coli in Magnesium Deficiency
}

\author{
By T. GUNTHER, LISELOTTE RICHTER AND \\ J. SCHMALBECK \\ Zentralinstitut für Biochemie und Biophysik and \\ Physiologisch-Chemisches Institut, Freie Universität Berlin, Germany
}

(Received 24 July 1974; revised 17 September 1974)

Growing bacteria in a magnesium-deficient medium causes loss of ribosomes (McCarthy, 1962), inhibition of nucleic acid (Kennell \& Kotoulas, 1967) and protein synthesis (Marchesi \& Kennell, 1967), inhibition of growth (McCarthy, 1962), inhibition of intracellular $\mathrm{K}^{+}$ accumulation (Günther \& Mariss, I968a), and changes in metabolism, especially a decrease in the capacity of oxidative phosphorylation (Günther \& Mariss, 1968b). Moreover, infoldings of the plasma membrane near the end of the cell and intracytoplasmic membranes are shown in Mg-starved Escherichia coli by electron microscopy (Fiil \& Branton, 1969; Lutsch \& Venker, 1969; Morgan, Rosenkranz \& Rose, 1966). For comparison with these morphological results we examined the content and composition of phospholipids in E. coli which had been $\mathrm{Mg}$-starved under comparable conditions. Total phospholipids increased on $\mathrm{Mg}$ starvation (Table I); this corresponds to the increase of membranes. Phosphate starvation also causes a reduction of ribosomes and growth rate (Horiuchi, Horiuchi \& Mizuno, 1959) and formation of intracytoplasmic membranes (Lutsch \& Venker, 1969). Thus certain nutrient deficiencies produce a complex alteration in the regulation of metabolism.

The phospholipid pattern changed during $\mathrm{Mg}$ deficiency, because the increase in phospholipid content was limited to phosphatidylethanolamine and cardiolipin. Expressed relative to total extracted phospholipids, there was more cardiolipin and less phosphatidylglycerol and phosphatidylethanolamine. An altered regulation of metabolism could again be the reason. This alteration could have been produced by differences in the Mg-dependence of the enzymes involved in the phospholipid turnover, but as the average intracellular $\mathrm{Mg}$ ionic activity (assuming there is no compartmentation) is essentially undiminished in Mg-deficient bacteria (Günther \& Dorn, 1969), this is unlikely. In Mg deficiency the concentrations of extracellular $\mathrm{Mg}$ and intracellular $\mathrm{K}^{+}$are reduced (Günther \& Mariss, 1968 $a$ ) so these ions may be involved. An effect of extracellular $\mathrm{Mg}$ ions on phospholipid metabolism has been shown in the $\mathrm{Na}^{+}$-sensitive mutant $E$. coli A324-I (Lusk \& Kennedy, 1972). Sodium ions inhibited growth of this strain and caused less synthesis of phosphatidylethanolamine and more of cardiolipin. High $\mathrm{Mg}, \mathrm{Ca}$ or $\mathrm{Sr}$ concentrations normalized growth and phospholipid metabolism without altering the intracellular $\mathrm{Na}^{+}$or $\mathrm{Mg}$ contents.

Relatively less phosphatidylglycerol and more cardiolipin were also observed after the transition from exponential to stationary phase (Cronan \& Vagelos, 1972) and after the addition of dinitrophenol, colicin K (Cavard, Rampini, Barber \& Polonowski, 1968) or penicillin (Stárka \& Moravová, 1970). According to Cronan \& Vagelos (1972), 'These manipulations, although very diverse, have one character in common, they all result in decreased cellular phosphorylating ability'. Guanosine tetraphosphate, however, which can regulate phospholipid synthesis (Merlie \& Pizer, 1973), probably does not always participate. The increase of guanosine tetraphosphate is small after addition of colicin or during phosphate starvation (Lazzarini, Cashel \& Gallant, I97I). 
Table I. Phospholipids of normal and Mg-deficient Escherichia coli

Total lipid phosphate Phosphatidylethanolamine Cardiolipin Phosphatidylglycerol Phosphatidylserine

\begin{tabular}{|c|c|c|c|}
\hline \multicolumn{4}{|c|}{ Lipid phosphate } \\
\hline \multicolumn{2}{|c|}{ Normal* } & \multicolumn{2}{|c|}{ Mg-deficient $\dagger$} \\
\hline$\mu \mathrm{mol} / \mathrm{g}$ dry $\mathrm{wt}$ & $\%$ total & $\mu \mathrm{mol} / \mathrm{g}$ dry wt & $\%$ total \\
\hline $105 \cdot 7$ 土2.5 & 100 & $148 \cdot 3 \pm 8 \cdot 3$ & 100 \\
\hline $82 \cdot 9 \pm 2 \cdot 6$ & $78 \cdot 4 \pm 2 \cdot 5$ & $107 \cdot 5 \pm 5 \cdot 9$ & $72 \cdot 5 \pm 4 \cdot 0$ \\
\hline II $\cdot 5 \pm$ I.O & $10.9 \pm 0.9$ & $23 \cdot 6 \pm 2 \cdot 4$ & $15 \cdot 9 \pm I \cdot 6$ \\
\hline $9 \cdot 0 \pm I \cdot 0$ & $8.5 \pm 0.9$ & $8 \cdot 9 \pm I \cdot 8$ & $6 \cdot 0 \pm 1 \cdot 2$ \\
\hline$I \cdot I \pm 0 \cdot I$ & $I \cdot 0 \pm 0 \cdot I$ & $3 \cdot 3 \pm 2 \cdot 0$ & $2 \cdot 2 \pm I \cdot 3$ \\
\hline
\end{tabular}

* Mean of 7 experiments, \pm S.D.

$\dagger$ Mean of 10 experiments, \pm s.D.

Escherichia coli BI 63 was grown aerobically at $37^{\circ} \mathrm{C}$ in glucose (0.75\%)-minimal medium in Erlenmeyer flasks by gassing with $95 \% \mathrm{O}_{2}-5 \% \mathrm{CO}_{2}$ (Günther \& Dorn, 1966). For Mg-deficient bacteria the concentration of $\mathrm{Mg}$ in the growth medium was $3 \mu \mathrm{M}$; for normal bacteria and $\mathrm{Mg}$-deficient bacteria, $\mathrm{I}$ and $5 \mathrm{lmedium}$ were used respectively. (Under these conditions, after $16 \mathrm{~h}$ the normal and $\mathrm{Mg}$-deficient bacteria had reached an absorbance at $405 \mathrm{~nm}$ of 0.7 and 0.1 respectively, corresponding to 0.4 and $0.06 \mathrm{~g}$ protein/1, and thereafter continued in the stationary phase.) Overnight cultures $(20 \mathrm{~h})$ were washed twice in double distilled water, frozen in liquid $\mathrm{N}_{2}$, and freeze-dried. The lipids were extracted with chloroform-methanol $(2: \mathrm{I}, \mathrm{v} / \mathrm{v})$. The extract was washed with $0.04 \% \mathrm{CaCl}_{2}$ (Folch, Lees \& Sloane Stanley, 1957). The phospholipids were chromatographed in two dimensions on silica gel thin-layer plates (Kieselgel 6o HR reinst, Merck, Darmstadt, Germany). Solvent system I was composed of $\mathrm{CHCl}_{3}-\mathrm{CH}_{3} \mathrm{OH}-\mathrm{H}_{2} \mathrm{O}$ (70:25:4, by vol.) and solvent system 2 of $\mathrm{CHCl}_{3}-\mathrm{CH}_{3} \mathrm{OH}-7 \mathrm{M}-\mathrm{NH}_{4} \mathrm{OH}(60: 35: 5$, by vol.) (Kanemasa, Akamatsu \& Nojima, 1967). The plates were developed in iodine vapour. The spots were scraped off and their phosphate contents determined according to Bartlett (1959). Reference compounds were obtained from Applied Science Laboratories, Inc., State College, Pennsylvania.

\section{REFERENCES}

Bartlett, G. R. (1959). Phosphorus assay in column chromatography. Journal of Biological Chemistry 234, $466-468$.

Cavard, D., Rampini, C., Barber, E. \& Polonowski, J. (I968). Activité phospholipasique et autres modifications du métabolisme des phospholipides consécutives a l'activation des colicines sur E. coli. Bulletin de la Société de Chimie Biologique 50, I455-1471.

Cronan, J. E. Jun. \& Vagelos, P. R. (1972). Metabolism and function of the membrane phospholipids of Escherichia coli. Biochimica et biophysica acta 265, 25-60.

Finl, A. \& Branton, D. (I969). Changes in the plasma membrane of Escherichia coli during magnesium starvation. Journal of Bacteriology 98, 1320-1327.

Folch, J., Lees, M. \& Sloane Stanley, G. H. (1957). A simple method for the isolation and purification of total lipids from animal tissues. Journal of Biological Chemistry 226, 497-509.

Günther, T. \& Dorn, F. (I966). Über die ATPase von E. coli в I63 und seiner K+-Mangelmutante в 525. Zeitschrift für Naturforschung 2ib, 1076-108I.

GÜNTHER, T. \& DORN, F. (1969). Über die intrazelluläre Mg-Ionenaktivität von E. coli-Zellen. Zeitschrift für Naturforschung $24 \mathrm{~b}, 713-717$.

Günther, T. \& Mariss, P. (1968a). Über den $\mathrm{K}^{+}$-Transport bei Mg-arm gewachsenen Zellen von $E$. coli. Zeitschrift für Naturforschung 23 b, 334-338.

GüNTHER, T. \& MARISs, P. (1968b). Über den Stoffwechsel magnesiumarm gewachsener Zellen von E. coli. Hoppe-Seyler's Zeitschrift für Physiologische Chemie 349, 623-63I.

Horiuchi, T., Horiuchi, S. \& Mizuno, D. (1959). Degradation of ribonucleic acid in Escherichia coli in phosphorus-deficient culture. Biochimica et biophysica acta 31, 570-572.

Kanemasa, Y., Akamatsu, Y. \& Nojma, S. (1967). Composition and turnover of the phospholipids in Escherichia coli. Biochimica et biophysica acta 144, 382-390.

Kennell, D. \& Kotoulas, A. (1967). Magnesium starvation of Aerobacter aerogenes. II. Rates of nucleic acid synthesis and methods for their measurement. Journal of Bacteriology 83, 345-356.

Lazzarini, R. A., Cashel, M. \& Gallant, J. (I97I). On the regulation of guanosine tetraphosphate levels in stringent and relaxed strains of Escherichia coli. Journal of Biological Chemistry 246, 438I-4385. 
LuSK, J. E. \& KENNEDY, E. P. (1972). Altered phospholipid metabolism in a sodium-sensitive mutant of Escherichia coli. Journal of Bacteriology ro9, 1034-1046.

LUTSCH, G. \& VenKer, P. (1969). Intracytoplasmatische Membranen in E. coli nach Magnesium-bzw. Phosphat-Mangel. Naturwissenschaften 56, 568.

MarChesi, S. L. \& KenNell, D. (1967). Magnesium starvation of Aerobacter aerogenes III. Protein metabolism. Journal of Bacteriology 93, 357-366.

MCCARTHY, B. J. (1962). The effects of magnesium starvation on the ribosome content of Escherichia coli. Biochimica et biophysica acta $55,880-888$.

MerLIE, J. P. \& PIZER, L. I. (1973). Regulation of phospholipid synthesis in Escherichia coli by guanosine tetraphosphate. Journal of Bacteriology 116, 355-366.

Morgan, C., Rosenkranz, H.S. \& Rose, H. M. (1966). Electron microscopy of magnesium-depleted bacteria. Journal of Bacteriology 91, 89I-895.

StÁRKA, J. \& Moravová, J. (1970). Phospholipids and cellular division of Escherichia coli. Journal of General Microbiology 60, 25I-257. 